\title{
On the Concentrating Defect in Cirrhosis of the Liver *
}

\author{
Hershel Jick, † Donald E. Kamm, Julian G. Snyder, Robert S. Morrison, \\ and Thomas C. Chalmers \\ (From the Clinical Pharmacology and Renal and Electrolyte Divisions of the Medical Service, \\ Lemuel Shattuck Hospital, Department of Public Health, Commonwealth of Massa- \\ chusetts, and the Departments of Medicine, Harvard Medical School and \\ Tufts University School of Medicine, Boston, Mass.)
}

The capacity of patients with cirrhosis of the liver to produce a dilute urine after a water load has been extensively investigated $(1,2)$. The concentrating ability of these patients has not been carefully studied, although the assumption has been made that a defect exists $(1,3)$.

The present studies describe the characteristics of the concentrating system in patients with cirrhosis and attempt to clarify the mechanisms involved in any existing defect.

\section{Methods}

Twenty-seven patients with cirrhosis of the liver of varying severity associated with chronic alcoholism and 17 patients with other chronic diseases were studied. Each patient was receiving at least $75 \mathrm{~g}$ of dietary protein and at least $1 \mathrm{~g}$ of dietary sodium per day. None gave a history of renal disease, and all had normal urinalysis, nonprotein nitrogen, and serum creatinine. No patients above the age of 65 were included. Except for the absence of azotemia or intrinsic renal disease, the cirrhotics represented a wide range of patients with this disease. The mean age of cirrhotics was 50 and ranged from 35 to 62 years. The degree of ascites ranged from no apparent ascites (seven patients) to massive ascites (three patients) and included varying degrees of protein depletion as estimated by degree of muscle wasting. The mean age of the 17 chronically ill patients without cirrhosis was 49 and ranged from 38 to 58 years, and they represented the only noncirrhotic patients in the medical service ( 180 beds) at a given time who satisfied the above criteria for inclusion in the study.

The degree of ascites and degree of muscle wasting were estimated in each cirrhotic by a scale of 0 to ++++ . Age and sex were recorded.

1) Special studies were carried out in nine patients with cirrhosis to evaluate and characterize the maximal

* Submitted for publication August 27, 1963; accepted October 17, 1963.

$\dagger$ This investigation was carried out during tenure as a Clinical Pharmacology Trainee and was supported by grants from the U. S. Public Health Service (H-4789, H-2324, and A-2334), and by gifts from G. D. Searle Co., Chicago, Ill. concentrating ability $\left(U_{\max }\right)$. These studies included measurement of urine osmolality ( $U_{\text {os } m}$ ) starting at 14 hours after the last oral intake and 10 hours after $5 \mathrm{U}$ of vasopressin in oil intramuscularly. Urine samples were obtained intermittently until a last sample was obtained after 21 to 25 hours of dehydration.

2) Volume and urea, ammonia, sodium, and potassium concentrations of $U_{\max }$ urines were measured in 11 cirrhotics. In other patients urine sodium excretion was recorded as 0 to ++++ based on the approximate percentage of the oral sodium intake excreted.

3) $U_{\max }$ after 16 hours of dehydration and $5 \mathrm{U}$ of vasopressin tannate in oil was determined in the $17 \mathrm{pa}$ tients with chronic disease other than cirrhosis. In eight of these patients selected at random, urine volume and urea, ammonia, sodium, and potassium concentrations were also determined.

4) In 16 cirrhotics, $U_{\max }$, negative free-water clearance $\left(\mathrm{T}^{\mathrm{c}} \mathrm{H}_{2} \mathrm{O}\right)$, clearance of inulin $\left(\mathrm{C}_{\mathrm{In}}\right)$ (four patients), or clearance of mannitol $\left(\mathrm{C}_{\mathbf{M a n}}\right)$ (nine patients), serum sodium, and serum potassium were measured. $\mathrm{U}_{\max }$ was obtained after 16 hours of dehydration and $5 \mathrm{U}$ of vasopressin tannate in oil. $\mathrm{T}_{\mathrm{H}_{2} \mathrm{O}}^{\mathrm{e}}$ was then determined by inducing osmotic diuresis with a rapid infusion of $10 \%$ mannitol containing approximately $200 \mathrm{mU}$ of aqueous vasopressin per hour after a priming solution of inulin, or mannitol, or both, and aqueous vasopressin. At least three collection periods were obtained for measurements of $\mathrm{C}_{\text {In }}$ and $\mathrm{C}_{\mathrm{Man} \text {. }}$.

5) Since a defect in $U_{\max }$ with normal $T^{{ }_{H z} \mathrm{O}}$ was noted in many patients, further studies were done on six of the above patients, and four normal healthy males, eating normal diets, as follows: after maximal osmotic diuresis was obtained, as described above, iv mannitol was stopped, and $U_{\text {osm }}$ was determined as osmolar clearance $\left(\mathrm{C}_{\text {osm }}\right)$ fell.

Eight of the 16 patients were studied while on a metabolic ward where they received $2 \mathrm{~g}$ of dietary sodium each day. The others were patients receiving varying amounts of dietary sodium $(>1 \mathrm{~g})$ on the regular medical ward.

Sodium and potassium concentrations were determined with a flame photometer. ${ }^{1}$ Urine and plasma osmolality were determined with a cryoscopic osmometer. ${ }^{2}$ Inulin was determined by the resorcinol method for fructose

1 Baird Associates, model DB-4, Cambridge, Mass.

2 Fiske, model B, Bethel, Conn. 
of Bacon and Bell (4) as modified by Higashi and Peters (5). Mannitol was determined by the method of Corcoran and Page (6). Urine urea and ammonia were determined in duplicate by a modification of the Van Slyke and Cullen method (7). $\mathrm{C}_{\text {osm }}$ was calculated from the formula $\mathrm{C}_{\mathrm{osm}}=\left(\mathrm{U}_{\mathrm{osm}} / \mathrm{P}_{\mathrm{osm}}\right) \mathrm{V}$. $\mathrm{T}_{\mathrm{H}_{2} \mathrm{O}}^{\mathrm{O}}$ was calculated from the formula $\mathrm{T}_{\mathrm{H}=\mathrm{O}}^{\mathrm{c}}=\mathrm{C}_{\mathrm{osm}}-\mathrm{V}$. $\quad\left(\mathrm{P}_{\mathrm{osm}}=\right.$ serum osmolality; $\mathrm{V}=$ urine flow.)

\section{Results}

1) Data obtained from nine patients with cirrhosis indicated that dehydration beyond 16 hours did not contribute significantly to an increase in $\mathrm{U}_{\max }$ (Table I). A mean difference of only $31 \pm$ $11 \mathrm{mOsm}$ per L (1 SE) or approximately $5 \%$ was obtained between urines voided after 21 to 25 hours of dehydration when compared with urines obtained after 16 hours of dehydration. The findings are consistent with data previously reported in hydropenic cirrhotics who demonstrated a decreased urine specific gravity and in whom dehydration beyond 16 hours did not produce a significant rise in specific gravity in any of the eight patients studied (8).

2) The mean $U_{\max }$ of 27 patients with cirrhosis obtained after 16 hours of dehydration was $651 \pm$ $25 \mathrm{mOsm}$ per $\mathrm{L}(1 \mathrm{SE})$. This value was significantly lower than the value of $812 \pm 31 \mathrm{mOsm}$ per L (Table II) obtained in noncirrhotics with chronic diseases $(p<0.01)$, and the value of $947 \pm 25 \mathrm{mOsm}$ per $\mathrm{L}$ previously reported in hospitalized patients without clinical evidence of renal disease (9). Although the noncirrhotic patients fulfilled the criteria of diet, age, and absence

TABLE I

Urine osmolality ( $\left.U_{\text {osm }}\right)$ during dehydration

\begin{tabular}{ccc}
\hline & \multicolumn{2}{c}{$U_{\text {Usm }}$} \\
\cline { 2 - 3 } Patient & $\begin{array}{c}\text { 16-hr } \\
\text { Dehydration }\end{array}$ & $\begin{array}{c}>21-\mathrm{hr} \\
\text { Dehydration }\end{array}$ \\
\hline & \multicolumn{2}{c}{ mOsm/L } \\
2 & $638^{\text {mos }}$ & 687 \\
3 & 608 & $716^{*}$ \\
4 & $667^{-}$ & $634^{*}$ \\
5 & 679 & $694^{*}$ \\
6 & 488 & 680 \\
7 & 686 & 507 \\
8 & 423 & $694^{*}$ \\
Mean & 605 & $465^{*}$ \\
1 SE & \pm 32 & 636 \\
& & \pm 39 \\
\hline
\end{tabular}

* Values represent at least 24 hours of dehydration.
TABLE II

Maximal urinary concentration $\left(U_{\max }\right)$ in noncirrhotics with chronic disease

\begin{tabular}{cccl}
\hline \hline & $\mathrm{U}_{\max }$ & Age & \\
\hline & $m O s m / L$ & & Diagnosis \\
1. & 758 & 49 & Cancer \\
2. & 776 & 45 & Cancer \\
3. & 730 & 48 & Cancer \\
4. & 680 & 55 & Diabetes \\
5. & 780 & 58 & Rheumatoid arthritis \\
6. & 759 & 57 & Chronic pulmonary disease \\
7. & 1,000 & 42 & Cancer \\
8. & 720 & 57 & Arteriosclerotic heart disease \\
9. & 742 & 54 & Rheumatoid arthritis \\
10. & 790 & 38 & Rheumatoid arthritis \\
11. & 771 & 58 & Rheumatoid arthritis \\
12. & 893 & 43 & Dermatitis \\
13. & 1,003 & 56 & Peripheral neuropathy \\
14. & 1,103 & 35 & Obesity \\
15. & 700 & 43 & Cancer \\
16. & 909 & 49 & Cancer \\
17. & 667 & 57 & Cancer \\
Mean & 812 & 49 & \\
SE & \pm 31 & \pm 2 & \\
\hline
\end{tabular}

of evident renal disease, the patients studied had been, for the most part, ill for many months or years.

3) The composition of $U_{\max }$ urines in 11 cirrhotics is shown in Table III. The urea concentration ( $U_{\text {Urea }}$ ) ranged from $105 \mu$ moles per $\mathrm{ml}$ to $370 \mu$ moles per $\mathrm{ml}$ (mean $=255 \pm 30$ ). Total urea $\left(U_{\text {Urea }} V\right)$ varied from 48 to $200 \mu$ moles per minute (mean $=145 \pm 20$ ). The ratio of urea to nonurea solute varied from 19 to $68 \%$ (mean $=46 \pm 5$ ). The same values for eight noncirrhotics are given in Table IV. There were no statistically significant differences in urea or potassium excretion between the two groups. Urinary sodium concentration $\left(\mathrm{U}_{\mathrm{Na}}\right)$ was significantly lower in cirrhotics $(\mathrm{p}<0.01)$.

Neither $U_{\text {Urea }}(r=0.483), U_{\text {Urea }} V(r=0.405)$, nor percentage of urea per nonurea solute $(r=-$ 0.278 ) were significantly correlated with $U_{\max }$ in cirrhotics.

4) Table $V$ summarizes the data in a group of 16 cirrhotics in whom more comprehensive studies were carried out. The mean $U_{\max }$ of this group was $688 \pm 33 \mathrm{mOsm}$ per L ( $1 \mathrm{SE}$ ), which is not significantly different from the $U_{\max }$ in the entire group of cirrhotics, but is significantly different $(p<0.01)$ from the patients with other chronic diseases.

The mean $\mathrm{T}^{\mathrm{c}}{ }_{\mathrm{H}^{2} \mathbf{O}}$ for the 16 patients studied was 
TABLE III

Composition of maximal urinary concentration in cirrhotics*

\begin{tabular}{|c|c|c|c|c|c|c|c|c|c|}
\hline Patient & $\mathrm{U}_{\max }$ & $\underset{U_{\max } \dagger}{\text { Calculated }}$ & $\mathrm{V}$ & $\mathrm{U}_{\mathrm{Na}}$ & UK & $U_{\text {Crea }}$ & $\mathrm{UNH}_{4}$ & UUreaV & $\frac{\text { Urea }}{\begin{array}{c}\text { Nonurea } \\
\text { solute }\end{array}}$ \\
\hline $\begin{array}{r}1 \\
2 \\
3 \\
4 \\
9 \\
10 \\
11 \\
12 \\
13 \\
14 \\
15\end{array}$ & $\begin{array}{c}m O s m / L \\
687 \\
716 \\
465 \\
634 \\
728 \\
470 \\
535 \\
578 \\
618 \\
460 \\
790\end{array}$ & $\begin{array}{c}m 0 s m / L \\
641 \\
641 \\
424 \\
598 \\
737 \\
428 \\
537 \\
528 \\
642 \\
407 \\
784\end{array}$ & $\begin{array}{c}m l / m i n \\
0.6 \\
0.5 \\
\\
0.6 \\
0.5 \\
0.5 \\
0.5 \\
0.4 \\
0.7 \\
0.5\end{array}$ & $\begin{array}{c}\mu E q / m l \\
83 \\
35 \\
13 \\
139 \\
32 \\
8 \\
152 \\
29 \\
118 \\
1 \\
69\end{array}$ & $\begin{array}{c}\mu E q / m l \\
67 \\
46 \\
59 \\
42 \\
142 \\
34 \\
54 \\
107 \\
82 \\
56 \\
112\end{array}$ & $\begin{array}{c}\text { Amoles } / \mathrm{ml} \\
279 \\
417 \\
232 \\
172 \\
333 \\
290 \\
105 \\
226 \\
120 \\
265 \\
370\end{array}$ & $\begin{array}{c}\mu E q / m l \\
31 \\
31 \\
24 \\
32 \\
28 \\
27 \\
10 \\
15 \\
23 \\
14 \\
36\end{array}$ & $\begin{array}{c}\text { moles } / \text { min } \\
167 \\
209 \\
\\
\\
200 \\
145 \\
53 \\
113 \\
48 \\
185 \\
185\end{array}$ & $\begin{array}{l}\% \\
45 \\
68 \\
28 \\
43 \\
19 \\
65 \\
48 \\
43 \\
65 \\
54 \\
29\end{array}$ \\
\hline $\begin{array}{l}\text { Mean } \\
\text { SE }\end{array}$ & $\begin{array}{r}607 \\
\pm 35\end{array}$ & $\begin{array}{r}578 \\
\pm 38\end{array}$ & $\begin{array}{r}0.53 \\
\pm 0.02\end{array}$ & $\begin{array}{r}62 \\
+16\end{array}$ & $\begin{array}{r}73 \\
\pm 10\end{array}$ & $\begin{array}{r}255 \\
\pm 30\end{array}$ & $\begin{array}{r}25 \\
\pm 3\end{array}$ & $\begin{array}{r}145 \\
\pm 20\end{array}$ & $\begin{array}{r}46 \\
\pm 5\end{array}$ \\
\hline
\end{tabular}

${ }^{*} \mathrm{U}_{\max }=$ maximal urinary concentration; $\mathrm{V}=$ rate of urine flow; $\mathrm{U}_{\mathrm{Na}}=$ urinary sodium concentration; $\mathrm{U}_{\mathrm{K}}=$ urinary potassium concentration; $U_{U r e a}=$ urea concentration; $U_{\mathbf{N H}_{4}}=$ ammonium concentration; $U_{U \text { rea }} V=$ total urea. $\dagger$ Urine osmolality calculated from the formula:

$$
\mathrm{U}_{\mathrm{osm}}=\left(\mathrm{U}_{\mathrm{Na}}+\mathrm{U}_{\mathrm{K}}+\mathrm{U}_{\mathrm{NH}_{4}}\right) \times 2+\mathrm{U}_{\mathrm{Urea}} .
$$

$4.8 \pm 0.44 \mathrm{ml}$ per minute ( $1 \mathrm{SE}$ ), which is not significantly different from the value of $5.1 \pm$ $0.33 \mathrm{ml}$ per minute obtained by Zak, Brun, and Smith (10) in normal subjects, despite the fact that the latter group was considerably younger than the group presented here. ${ }^{3}$

The mean glomerular filtration rate was $85 \pm$ $9.8 \mathrm{ml}$ per minute ( $1 \mathrm{SE}$ ), which is somewhat

\footnotetext{
${ }^{3}$ Values given by $\mathrm{Zak}$ and associates are corrected for surface area; however, recalculation to uncorrected values reveals no essential change in mean $\mathrm{T}_{\mathrm{H}_{2} \mathrm{O}}^{\mathrm{c}}$ (mean uncorrected $=5.0 \mathrm{ml}$ per minute).
}

lower than the mean of $101 \pm 3.8 \mathrm{ml}$ per minute reported by Zak and associates (10).

Since protein depletion, potassium depletion, inadequate delivery of sodium to distal sites, age, and glomerular filtration rates are thought to affect the concentrating mechanism under some circumstances, associations involving estimates of these states were calculated and appear in Table VI. Despite the varying degrees of fluid retention and protein depletion neither $\mathrm{U}_{\max }$ nor $\mathrm{T}^{\mathbf{c}}{ }_{\mathrm{H}_{2} \mathrm{O}}$ was associated with degree of ascites, serum po-

TABLE IV

Composition of maximal urinary concentration in noncirrhotics*

\begin{tabular}{|c|c|c|c|c|c|c|c|c|c|}
\hline Patient & $\mathrm{U}_{\max }$ & $\underset{U_{\max } \text { Calculated }^{\text {Cal }}}{ }$ & v & $\mathrm{U}_{\mathrm{Na}}$ & $\mathrm{U}_{\mathrm{K}}$ & $U_{\text {Urea }}$ & $\mathrm{UNH}_{\mathrm{NH}}$ & U Ures $\mathrm{V}$ & $\frac{\text { Urea }}{\begin{array}{c}\text { Nonurea } \\
\text { solute }\end{array}}$ \\
\hline $\begin{array}{l}1 \\
2 \\
3 \\
4 \\
5 \\
6 \\
7 \\
8 \\
9\end{array}$ & $\begin{array}{c}\text { mOsm/L } \\
758 \\
776 \\
730 \\
680 \\
780 \\
759 \\
1,000 \\
720 \\
742\end{array}$ & $\begin{array}{c}m O s m / L \\
688 \\
744 \\
702 \\
644 \\
681 \\
649 \\
1,014 \\
733 \\
699\end{array}$ & $\begin{array}{c}m l / m i n \\
0.2 \\
0.4 \\
0.3 \\
0.3 \\
0.8 \\
0.7 \\
0.3 \\
0.7 \\
0.8\end{array}$ & $\begin{array}{c}\mu E q / m l \\
50 \\
142 \\
77 \\
68 \\
150 \\
184 \\
202 \\
136 \\
158\end{array}$ & $\begin{array}{c}\mu E q / m l \\
40 \\
26 \\
68 \\
87 \\
60 \\
60 \\
138 \\
86 \\
76\end{array}$ & $\begin{array}{c}\text { Amoles } / \mathrm{ml} \\
430 \\
330 \\
318 \\
240 \\
121 \\
109 \\
294 \\
239 \\
177\end{array}$ & $\begin{array}{c}\mu E q / m l \\
39 \\
39 \\
47 \\
47 \\
26 \\
22 \\
20 \\
25 \\
27\end{array}$ & $\begin{array}{c}\text { Amoles/min } \\
86 \\
132 \\
95 \\
72 \\
97 \\
76 \\
46 \\
90 \\
141\end{array}$ & $\begin{array}{l}\% \\
63 \\
44 \\
45 \\
38 \\
18 \\
17 \\
28 \\
33 \\
25\end{array}$ \\
\hline $\begin{array}{l}\text { Mean } \\
\text { SE }\end{array}$ & $\begin{array}{r}772 \\
\pm 30\end{array}$ & $\begin{array}{r}728 \\
\pm 30\end{array}$ & $\begin{array}{r}0.5 \\
\pm 0.8\end{array}$ & $\begin{array}{c}130 \\
\pm 17.7\end{array}$ & $\begin{array}{c}71 \\
\pm 10.7\end{array}$ & $\begin{aligned} & 251 \\
\pm & 37\end{aligned}$ & $\begin{array}{c}32 \\
\pm 3.5\end{array}$ & $\begin{array}{c}93 \\
\pm 9.7\end{array}$ & $\begin{array}{c}35 \\
\pm 5.3\end{array}$ \\
\hline
\end{tabular}

* Abbreviations as in Table III.

$\dagger$ Urine osmolality calculated from the formula:

$$
\mathrm{U}_{\mathrm{osm}}=\left(\mathrm{U}_{\mathrm{Na}}+\mathrm{U}_{\mathrm{K}}+\mathrm{U}_{\mathrm{NH}_{4}}\right) \times 2+\mathrm{U}_{\text {Urea. }}
$$


ON THE CONCENTRATING DEFECT IN CIRRHOSIS OF THE LIVER

TABLE V

Combined data on the concentrating mechanism in sixteen cirrhotics*

\begin{tabular}{|c|c|c|c|c|c|c|c|c|c|c|}
\hline Patient & Sex & Age & $U_{\max }$ & $\mathrm{T}^{\mathrm{c}_{\mathrm{H}_{2} \mathrm{O}}}$ & GFR & $\underset{\mathrm{Na}}{\text { Serum }}$ & $\underset{\mathbf{K}}{\text { Serum }}$ & $\begin{array}{l}\text { Degree of } \\
\text { ascites }\end{array}$ & $\mathrm{UNa}_{\mathrm{Na}}$ & $\begin{array}{c}\text { Muscle } \\
\text { wasting }\end{array}$ \\
\hline & & & $m O s m / L$ & $m l / m i n$ & $m l / m i n$ & $m E q / L$ & $m E q / L$ & & & \\
\hline 1 & $F$ & 42 & 628 & 5.1 & & 127 & 3.0 & + & ++ & $+t$ \\
\hline $4 \dagger$ & M & 60 & 744 & 4.9 & 139 & 138 & 4.2 & $+t+t$ & & + \\
\hline 5 & $\mathrm{M}$ & 51 & 679 & 8.3 & 112 & 139 & 4.5 & 0 & & 0 \\
\hline 14 & $\mathrm{~F}$ & 54 & 490 & 4.9 & 78 & 133 & 3.4 & + & + & $+t+$ \\
\hline 16 & $F$ & 49 & 700 & 1.7 & 40 & 142 & 5.0 & $+t+t$ & 0 & $+t+$ \\
\hline 17 & $\mathrm{~F}$ & 41 & 619 & 2.4 & 51 & 141 & 3.8 & ++ & 0 & $+t$ \\
\hline 18 & $\mathrm{~F}$ & 43 & 409 & 3.7 & 78 & 144 & 4.1 & & $+t$ & + \\
\hline 19 & $\mathbf{M}$ & 39 & 853 & 5.4 & 86 & 142 & 4.1 & 0 & $+t+$ & + \\
\hline 20 & $\mathrm{~F}$ & 62 & 545 & 3.0 & 49 & 139 & 4.3 & & $+t$ & + \\
\hline 21 & M & 44 & 880 & 5.2 & 154 & 131 & 5.0 & & & + \\
\hline 22 & $\mathbf{M}$ & 57 & 710 & 4.8 & 69 & 141 & 3.9 & + & $+t+t$ & 0 \\
\hline 23 & $\mathbf{M}$ & 60 & 680 & 5.5 & 108 & 133 & 3.9 & + & & 0 \\
\hline 24 & $\mathbf{M}$ & 35 & 667 & 4.7 & 52 & 140 & 4.8 & + & $+t+$ & + \\
\hline 25 & $\mathrm{~F}$ & 55 & 728 & 6.4 & & 138 & 4.0 & 0 & & + \\
\hline 26 & $\mathbf{M}$ & 42 & 875 & 4.3 & & 136 & 4.8 & $+t+t$ & & $+t$ \\
\hline 27 & $\mathbf{M}$ & 54 & 794 & 7.0 & 87 & 144 & 5.2 & 0 & $+t+$ & 0 \\
\hline $\begin{array}{l}\text { Mean } \\
\text { SE }\end{array}$ & & 50 & $\begin{array}{r}688 \\
+33\end{array}$ & $\begin{array}{c}4.8 \\
+0.44\end{array}$ & $\begin{array}{l}85 \\
\pm 9.8\end{array}$ & $\begin{array}{l}138 \\
\pm 1.0\end{array}$ & $\begin{array}{c}4.3 \\
\pm 0.11\end{array}$ & & & \\
\hline
\end{tabular}

* $\mathrm{U}_{\max }=$ maximal urinary concentration; $\mathrm{T}_{\mathrm{H}_{2} \mathrm{O}}=$ negative free-water clearance; $\mathrm{GFR}=$ glomerular filtration rate; $\mathrm{U}_{\mathrm{Na}}=$ urinary sodium excretion.

$\dagger$ Patient 4 was undergoing a spontaneous diuresis during this study.

tassium, muscle wasting, ability to excrete sodium, or serum sodium. Neither $U_{\max }(r=+$ $(0.280)$ nor $\mathrm{T}^{\mathrm{c}}{ }_{\mathrm{H}_{2} \mathrm{O}}(\mathrm{r}=+0.126)$ was significantly correlated with age. $U_{\max }$ was not significantly correlated with the glomerular filtration rate $(\mathrm{r}=+0.470)$, but $\mathrm{T}_{\mathbf{H}_{2} \mathrm{O}}$ was $(\mathrm{r}=+0.593)$ $(\mathrm{p}<0.05)$. As expected, there was a positive association between muscle wasting and degree of ascites $(p<0.05)$ and a negative association $(p<0.01)$ between degree of ascites and ability to excrete sodium. No significant correlation between $\mathrm{U}_{\max }$ and $\mathrm{T}^{\mathrm{c}}{ }_{\mathrm{H}_{2} \mathrm{O}}$ was found $(\mathrm{r}=+0.315)$. 5) In the four healthy males and in each patient with cirrhosis, straight lines were fitted to the values of $\mathrm{T}^{\mathrm{c}} \mathrm{H}_{2} \mathrm{O}$ for each $\mathrm{C}_{\mathrm{osm}}$ during the ascending portion of the $\mathrm{T}^{\mathrm{c}}{ }_{\mathrm{H}_{2} \mathrm{O}}$ curve $\left(\mathrm{C}_{\mathrm{osm}}\right.$ rising $)$

TABLE VI

Associations of clinical and laboratory findings in cirrhotic patients*

\begin{tabular}{|c|c|c|c|c|c|c|c|c|}
\hline & Age & $\mathrm{U}_{\max }$ & $\mathrm{T}_{\mathrm{H}_{2} \mathrm{O}}$ & Ascites & $\mathrm{U}_{\mathrm{Na}} \mathrm{V}$ & $\begin{array}{c}\text { Muscle } \\
\text { wasting }\end{array}$ & $\begin{array}{l}\text { Serum } \\
\text { sodium }\end{array}$ & GFR \\
\hline $\mathrm{U}_{\max }$ & 0 & & & & & & & \\
\hline $\mathrm{T}^{\mathbf{c}_{\mathrm{H}_{2} \mathrm{O}}}$ & 0 & 0 & & & & & & \\
\hline Ascites & 0 & 0 & 0 & & & & & \\
\hline $\mathrm{U}_{\mathrm{Na}} \mathrm{V}$ & 0 & 0 & 0 & -- & & & & \\
\hline $\begin{array}{l}\text { Muscle } \\
\text { wasting }\end{array}$ & 0 & 0 & 0 & + & - & & & \\
\hline $\begin{array}{l}\text { Serum } \\
\text { sodium }\end{array}$ & 0 & 0 & 0 & 0 & 0 & 0 & & \\
\hline GFR & 0 & 0 & + & 0 & 0 & 0 & 0 & \\
\hline $\begin{array}{l}\text { Serum } \\
\text { potassium }\end{array}$ & $\mathbf{0}$ & 0 & 0 & 0 & 0 & 0 & 0 & 0 \\
\hline
\end{tabular}

* These data are based on 15 patients (except for GFR, which was obtained in 13 patients). Data were analyzed by correlation methods if they were scalar, otherwise by chi square. $0=$ no association; + or - , positive or negative association at $\mathrm{p}<0.05 ;--$, negative association at $\mathrm{p}<0.01$. $\mathrm{U}_{\max }=\operatorname{maximal}$ urinary concentration; $\mathrm{T}^{\mathrm{c}} \mathrm{H}_{2} \mathrm{O}=\mathrm{n}^{\mathrm{O}} \mathrm{na}$ tive free-water clearance; $\mathrm{U}_{\mathrm{Na}} \mathrm{V}=$ urinary sodium excretion; $\mathrm{GFR}=$ glomerular filtration rate. 


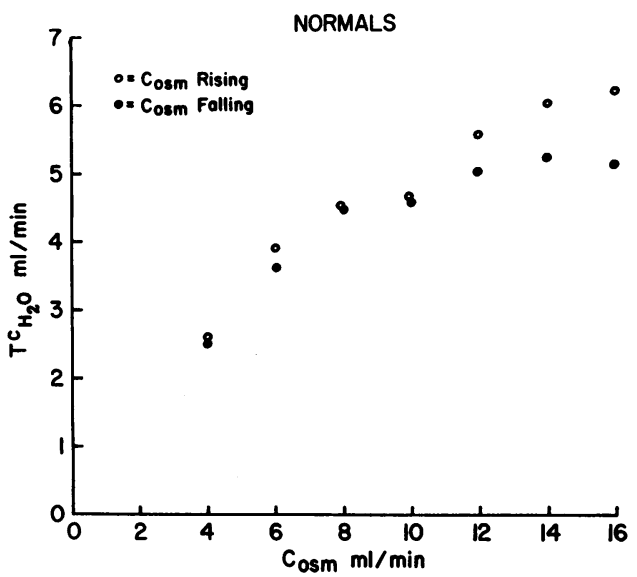

Fig. 1. GRaph of NEgative FREE-WATER CleARANCE $\left(\mathrm{T}^{\mathbf{c}} \mathrm{H}_{2} \mathrm{O}\right)$ VERSUS OSMOLAR CLEARANCE ( $\left.\mathrm{C}_{\mathrm{Osm}}\right)$ DURING OSMOTIC DIURESIS IN NORMAL SUBJECTS. All $\mathrm{C}_{\text {osm } m}$ and corresponding $\mathrm{T}^{\mathbf{c}} \mathrm{H}_{2} \mathrm{O}$ values are grouped about successive 2 - $\mathrm{ml}$ increments in $\mathrm{C}_{\text {osm }}$ and represent mean values for the group.

by the method of least squares. Values of $\mathrm{T}^{\mathrm{c}}{ }_{\mathrm{H}_{2} \mathrm{O}}$ obtained after the peak of osmotic diuresis $\left(\mathrm{C}_{\text {osm }}\right.$ falling) were compared with expected values obtained from the calculated line.

To test the regularity of deviations of the descending points, the mean deviation was calculated and tested by $t$. In each normal subject there was no significant deviation from the calculated line, with most points in the descending portion of the curve falling directly on the calculated line.

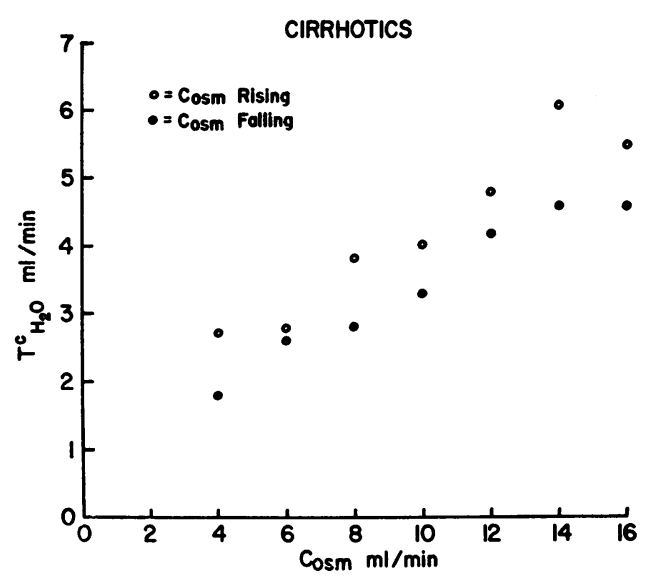

Fig. 2. Graph of Negative free-water clearance ( $\mathrm{T}^{\mathrm{c}}{ }_{\mathrm{H}, \mathrm{O}}$ ) VERSUS OSMOLAR CLEARANCE ( $\mathrm{C}_{\mathrm{og} m}$ ) DURING OSMOTIC DIURESIS IN CIRRHOTIC SUBJECTS. All $\mathrm{C}_{\text {osm }}$ and corresponding $\mathrm{T}^{\mathrm{c}} \mathrm{H}_{2 \mathrm{O}}$ values are grouped about successive 2-ml increments in $\mathrm{C}_{\text {osm } m}$ and represent mean values for the group.
TABLE VII

A representative experiment measuring negative free-water clearance before and after the peak of osmotic diuresis in normal subjects*

\begin{tabular}{|c|c|c|c|c|c|}
\hline & Vol & Uosm $_{\text {osm }}$ & $\mathrm{C}_{\mathrm{osm}}$ & $\mathrm{T}^{{ }^{6}} \mathrm{H}_{2} \mathrm{O}$ & $P_{\text {osm }}$ \\
\hline $\begin{array}{l}\min \\
0 \text { to } 95\end{array}$ & $\begin{array}{c}m l / \min \\
0.8\end{array}$ & $\underset{865}{\mu O s m / m l}$ & $\underset{2.3}{m l / m i n}$ & $\underset{1.5}{m l / m i n}$ & $n / m i$ \\
\hline
\end{tabular}

$10210 \%$ mannitol with aqueous vasopressin at $15 \mathrm{ml} / \mathrm{min}$

$\begin{array}{lrrrrr}102 \text { to } 131 & 1.6 & 757 & 4.1 & 2.5 & 280 \\ 131 \text { to } 143 & 3.4 & 582 & 6.9 & 3.5 & \\ 143 \text { to } 152 & 4.3 & 563 & 8.6 & 4.3 & \\ 152 \text { to } 161 & 4.4 & 553 & 8.5 & 4.1 & \\ 161 \text { to } 170 & 5.5 & 542 & 10.4 & 4.9 & \\ 170 \text { to } 179 & 6.0 & 520 & 10.9 & 4.9 & \\ 179 \text { to } 192 & 8.0 & 496 & 12.9 & 4.9 & \\ 192 \text { to } 200 & 9.4 & 468 & 15.2 & 5.8 & 290 \\ 200 \text { to } 207 & 11.4 & 451 & 17.7 & 6.3 & \\ & & & & & \\ & & \text { Infusion stopped } & & \\ 207 \text { to } 215 & 11.9 & 449 & 18.4 & 6.5 & \\ 215 \text { to } 225 & 10.3 & 453 & 16.1 & 5.8 & \\ 225 \text { to } 235 & 9.3 & 462 & 14.8 & 5.5 & \\ 235 \text { to } 245 & 7.9 & 472 & 13.1 & 5.2 & \\ 245 \text { to } 255 & 7.2 & 481 & 12.2 & 5.0 & \\ 255 \text { to } 265 & 7.0 & 488 & 12.0 & 5.0 & \\ 265 \text { to } 275 & 6.0 & 503 & 10.6 & 4.6 & 282 \\ 275 \text { to } 285 & 5.3 & 514 & 9.6 & 4.3 & \\ 285 \text { to } 295 & 4.6 & 543 & 8.8 & 4.2 & \\ 295 \text { to } 315 & 3.0 & 621 & 6.6 & 3.6 & \\ \end{array}$

$* \mathrm{U}_{\text {osm }}=$ urine osmolality; $\mathrm{C}_{\mathrm{osm}}=$ osmolar clearance; $\mathrm{T}^{\mathrm{c}} \mathrm{H}_{2} \mathrm{O}=$ negative free-water clearance: $P_{\mathrm{osm}}=$ plasma osmolality.

In each cirrhotic, however, the mean deviation was below the calculated line. In two cases the fall was of borderline significance $(p<0.05)$ and in one case highly significant $(\mathrm{p}<0.01)$.

TABLE VIII

$A$ representative experiment measuring negative free-water clearance before and after the peak of osmotic diuresis in a cirrhotic*

\begin{tabular}{|c|c|c|c|c|c|}
\hline Time & Vol & $\mathrm{U}_{\text {osm }}$ & $\mathrm{C}_{\text {osm }}$ & $\mathrm{T}^{\mathrm{T}} \mathrm{H}_{2} \mathrm{O}$ & Posm \\
\hline $\min$ & $m l / m i n$ & $\mu O s m / m l$ & $m l / \min$ & $\operatorname{ml} / \min$ & $\mu O s m / m l$ \\
\hline 0 to 52 & 0.5 & 728 & 1.2 & 0.7 & 283 \\
\hline 91 & \multicolumn{5}{|c|}{$\begin{array}{c}\text { Constant infusion } 10 \% \text { mannitol with aqueous } \\
\text { vasopressin at } 15 \mathrm{ml} / \mathrm{min}\end{array}$} \\
\hline 52 to 141 & 1.3 & 663 & 3.0 & 1.7 & \\
\hline 141 to 159 & 1.9 & 598 & 4.0 & 2.1 & 290 \\
\hline 159 to 174 & 4.6 & 557 & 8.8 & 4.2 & \\
\hline 174 to 186 & 8.2 & 518 & 14.6 & 6.4 & \\
\hline 186 to 195 & 9.4 & 500 & 15.7 & 6.3 & 300 \\
\hline 195 to 225 & 13.9 & 432 & 20.5 & 6.6 & \\
\hline \multicolumn{6}{|c|}{ Infusion stopped } \\
\hline 225 to 236 & 13.0 & 404 & 17.5 & 4.5 & \\
\hline 236 to 248 & 11.7 & 412 & 16.6 & 4.9 & 291 \\
\hline 248 to 258 & 10.5 & 417 & 15.1 & 4.6 & \\
\hline 258 to 269 & 8.0 & 425 & 11.7 & 3.7 & \\
\hline 269 to 279 & 6.2 & 437 & 9.3 & 3.1 & 285 \\
\hline 279 to 290 & 6.3 & 449 & 9.8 & 3.5 & \\
\hline 290 to 322 & 4.5 & 483 & 7.6 & 3.1 & \\
\hline 322 to 344 & 1.9 & 583 & 3.8 & 1.9 & \\
\hline
\end{tabular}

* Subject no. 25. Abbreviations as in Table VII. 
These findings are further illustrated by Figure 1 , which shows the mean curves of $\mathrm{T}^{\mathrm{c}} \mathrm{H}_{2} \mathrm{O}$ versus $C_{o s m}$ during osmotic diuresis, as $C_{o s m}$ is increasing and then as $C_{o s m}$ falls in four normal subjects, and Figure 2, which shows the same curves for cirrhotics. Except at high rates of $C_{\text {osm }}$, normal subjects were able to maintain their ability to conserve free water after the peak of diuresis (Table VII) when $\mathrm{C}_{\text {osm }}$ was falling, as shown by comparable $\mathrm{T}^{\mathrm{c}}{ }_{\mathrm{H}_{2} \mathrm{O}}$ for a given $\mathrm{C}_{\text {osm }}$ at $\mathrm{C}_{\text {osm }}$ below $10 \mathrm{ml}$ per minute (Figure 1). Cirrhotics did not improve water conservation after a mannitol infusion (Table VIII) and actually seemed to conserve water more poorly, as demonstrated by a mean $\mathrm{T}^{\mathrm{c}}{ }_{\mathrm{H}_{2} \mathrm{O}}$ for the six patients, which was invariably lower for a given $\mathrm{C}_{\text {osm }}$ after the peak of osmotic diuresis (Figure 2).

\section{Discussion}

A defect in $U_{\max }$ clearly exists in patients with cirrhosis, as shown by a mean value of $651 \mathrm{mOsm}$ per $\mathrm{L}$ obtained in this study for 27 patients, who were not rigidly salt restricted. Despite the low $\mathrm{U}_{\max }$, in the group studied, the mean $\mathrm{T}^{\mathrm{c}}{ }_{\mathrm{H}_{2} \mathrm{O}}$ of 4.8 $\mathrm{ml}$ per minute, obtained in 16 patients, is comparable to the mean value for normal subjects reported by Zak and associates (10) and therefore is considered to be normal. The range of 1.7 to $8.3 \mathrm{ml}$ per minute obtained in the present study was similar to the range of 1.5 to $7.4 \mathrm{ml}$ per minute obtained in normal subjects, and the standard errors of the mean were comparable ( 0.44 and $0.33 \mathrm{ml}$ per minute, respectively). The data of Zak and associates (10) show that a maximal $\mathrm{T}^{\mathrm{c}}{ }_{\mathrm{H}_{2} \mathrm{O}}$ below $3.5 \mathrm{ml}$ per minute occurred in $14 \%$ of the patients reported, thus indicating that such values are not necessarily "abnormally" low, but rather represent one end of the normal distribution of this measure of renal function. In the present studies a comparable group of cirrhotics (19\%) exhibited a maximal $\mathrm{T}^{\mathrm{c}} \mathrm{H}_{2} \mathrm{O}$ below $3.5 \mathrm{ml}$ per minute.

The $U_{\max }$ in the group of cirrhotics presented was not correlated with sodium excretion, urea excretion, degree of ascites, muscle wasting, serum sodium, serum potassium, or glomerular filtration rate. The $U_{\max }$ defect does not appear to result from chronic illness per se, since a comparable group of chronically ill patients without cirrhosis exhibited a $U_{\max }$ that was significantly higher than the value for cirrhotics (though somewhat lower than normal). These data therefore suggest that the $U_{\max }$ defect is specific for the disease rather than directly related to any particular complication of the disease.

The existence of a defect in the ability to conserve water in cirrhotics is not surprising in view of the well-documented defect of free-water formation in some of these patients $(1,2)$. Many investigators have postulated a defective delivery of sodium to the ascending loop of Henle and distal tubule in some patients with cirrhosis $(2,11)$. Schedl and Bartter supported this thesis by demonstrating that a mannitol diuresis improved the ability of cirrhotics to form free water, presumably owing to increased delivery of sodium to distal sites (2).

Since the above postulate is consistent with current physiologic concepts and reinforced by experimental evidence, it is reasonable to ascribe a concentrating defect in these patients also to inadequate sodium delivery to distal sites. Furthermore, the normal $\mathrm{T}^{\mathbf{C}_{2} \mathrm{O}}$ of these patients is compatible, since increased delivery during osmotic diuresis might provide the medullary interstitium with enough extra sodium to correct the pre-existing defect and produce a normal $\mathrm{T}^{\mathrm{c}}{ }_{\mathrm{H}^{2} \mathrm{O}}$.

The data on $\mathrm{T}^{\mathrm{C}_{\mathrm{H}_{2} \mathrm{O}}}$ versus $\mathrm{C}_{\mathrm{osm}}$ after the peak of osmotic diuresis (Figures 1 and 2) indicate that the above explanation is not sufficient. The ability of normal subjects studied to maintain $\mathrm{T}^{\mathbf{c}}{ }_{\mathrm{H}_{2} \mathrm{O}}$ for a given $\mathrm{C}_{\text {osm }}$ shortly after the peak of osmotic diuresis is consistent with the findings in normal dogs (12). The data for cirrhotics indicate that water conservation is not improved, but is actually poorer after osmotic diuresis. This finding suggests that increased sodium delivery did not produce a fundamental correction of the defect that led to the decreased $U_{\max }$. Furthermore, there appeared to be no shortage of sodium delivery in many of the patients, since they were excreting significant quantities of sodium in their urine each day. This finding also indicates that delivery of sodium to the distal nephron is not the only factor involved in water conservation in these patients. The normal $\mathrm{T}_{\mathrm{H}_{2} \mathrm{O}}$ in these patients indicates that insensitivity to antidiuretic hormone $(\mathrm{ADH})$ is not responsible for defective $\mathrm{U}_{\max }$ and also indicates that a normal capacity to 
reabsorb sodium exists in the ascending loop of Henle. A normal $\mathrm{T}^{\mathbf{c}}{ }_{\mathbf{H}_{2} \mathrm{O}}$ is not consistent with the hypothesis that decreased urea excretion was responsible for the $U_{\max }$ defect, since subjects with this abnormality have a marked decrease in $\mathrm{T}^{\mathrm{c}}{ }_{\mathrm{H}_{2} \mathrm{O}}$ (13). Furthermore, urea excretion was not abnormal in the present studies.

Increased body hydration and low total body potassium have been associated with defects in $\mathrm{U}_{\max }(14-16)$. Although cirrhotics tend to have both, individuals with these entities also have decreased $\mathrm{T}_{\mathbf{H}_{2} \mathrm{O}}$, which places them in a different category from the patients presented. Furthermore, neither $\mathrm{U}_{\max }$ nor $\mathrm{T}^{\mathrm{c}} \mathrm{H}_{2} \mathrm{O}$ was correlated with serum potassium, muscle wasting, or degree of ascites in the present studies.

The positive correlation of $\mathrm{T}^{\mathrm{c}} \mathrm{H}_{2} \mathrm{O}$ with glomerular filtration rate is not surprising, since this correlation might well exist in normal subjects. The lack of correlation between $U_{\max }$ and glomerular filtration rate suggests that the latter was not primarily responsible for the $U_{\max }$ defect although it may contribute in some patients.

In cirrhosis a defect apparently exists in the ability to produce a maximal $\mathrm{U}_{\mathrm{osm}} / \mathrm{P}_{\mathrm{osm}}$ ratio within the normal range. The capacity to maintain this abnormally low maximal $\mathrm{U} / \mathrm{P}$ ratio is striking as illustrated in Patient 5, who lowered $\mathrm{U}_{\text {osm }}$ by only $94 \mathrm{mOsm}$ per L (from 679 to 585) while going from a $\mathrm{C}_{\text {osm }}$ of $1.5 \mathrm{ml}$ per minute to $16.5 \mathrm{ml}$ per minute. This is in contrast to normal subjects who drop $U_{\text {osm }}$ quickly as $C_{\text {osn }}$ goes up (Figure 3) (17).

The co-existence of a defect in $U_{\max }$ and a normal $\mathrm{T}^{\mathrm{c}}{ }_{\mathrm{H}_{2} \mathrm{O}}$ has been described in one other clinical disease, sickle-cell disease in children (18, 19). The authors in one article (18) speculate that the medullary circulation in these patients is a less efficient trap and more effectively removes solute and water so that medullary hypertonicity is decreased, but the capacity to remove an increased water load from the interstitium during solute diuresis is unimpaired. These authors ruled out anoxia, defective sodium transport, and capillary vascular occlusion as responsible, but were unable to shed light on the nature of the abnormality.

Perillie and Epstein have recently shown that erythrocytes containing S-hemoglobin become sickled when they are immersed in hyperosmotic solutions (20). They suggested that the hypertonic milieu of the renal medulla promotes sickling in patients with sickle-cell disease and that this phenomenon restricts medullary blood flow by increasing blood viscosity and affects sodium transport in the loop of Henle secondary to hypoxia.

One possible explanation of the data in cirrhotics also relates to the importance of the medullary circulation that acts as a countercurrent ex-

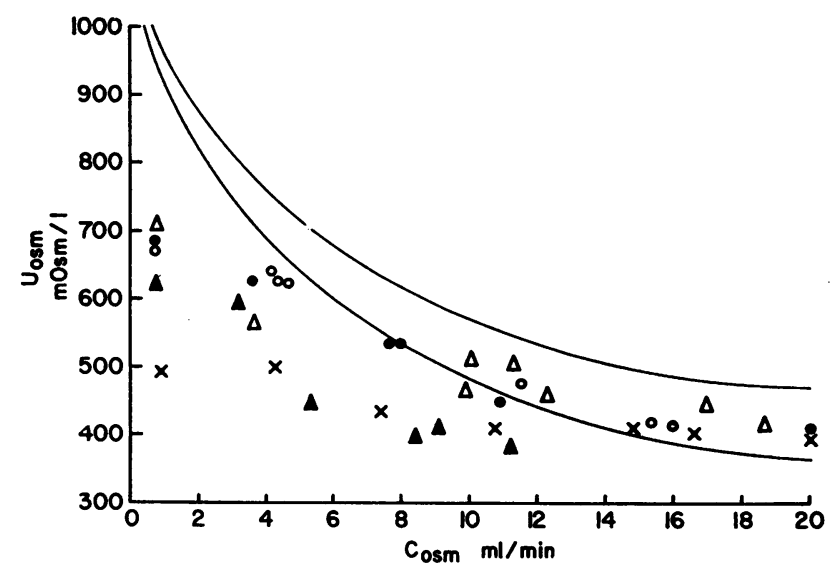

Fig. 3. Graph of urine osmolality (Uosm) versus osMOLAR CLEARANCE (Cosm) IN FIVE REPRESENTATIVE CIRRHotic AND NORMAL SUBJECTS. The symbols represent different patients with cirrhosis. The solid lines represent the range for normal subjects abstracted from the data of Rapoport, Brodsky, West, and Mackler (17) and Zak and associates (10). 
changer. According to current thinking, increased rate of flow in the vasa recta would lead to less efficient trapping of sodium in the medulla and therefore less hypertonicity (21). Increased medullary blood flow could exist in cirrhotics in association with shunting of blood around the glomerular capillaries. This situation could exist in spite of a normal quantity of sodium being reabsorbed by the ascending loop of Henle. Vascular shunts have been demonstrated in cirrhotics and have been postulated to explain some of the frequent findings in this disease, such as spider nevi and clubbing (22).

If this is indeed the explanation for the $U_{\max }$ defect in cirrhosis, then one may explain the normal $\mathrm{T}^{\mathrm{c}}{ }_{\mathrm{H}_{2} \mathrm{O}}$ either by postulating that a rapid mannitol infusion minimizes the effects of such shunts by decreasing circulation to the medulla, or by postulating that rapid medullary blood flow, while imposing restriction on the maximal $\mathrm{U} / \mathrm{P}$ ratio, does not restrict free water reabsorption at high urine flow rates where a high $U / P$ ratio is not required. The latter explanation seems more reasonable because of the data presented here which suggest that a mannitol infusion per se does not contribute to correction of the defect in water conservation which results in a low $U_{\max }$. Furthermore, $\mathrm{T}^{\mathrm{c}} \mathrm{H}_{2} \mathrm{O}$ formation is probably primarily dependent on simultaneous active sodium pumping in the ascending loop of Henle, limited only by a maximal $U / P$ ratio at low flow rates and maximal $\mathrm{T}^{\mathbf{c}}{ }_{\mathrm{H}_{2} \mathrm{O}}$ at high flow rates. Indeed, osmotic diuresis has been shown to increase rather than decrease medullary blood flow (21). If this is so, then a further increase in medullary circulation added to the postulated initial abnormally high flow in cirrhotics may explain the inability of these patients to recover their maximal ability to conserve water as rapidly as normal subjects after the peak of osmotic diuresis.

The lack of correlation between the characteristics of the concentrating system and the clinical status of patients with cirrhosis suggests that a fundamental abnormality of renal function exists in association with this disease. As is true with other complications of cirrhosis, this abnormality may be of varying severity in individual patients and apparently is not always correlated with the severity of the disease.

\section{Summary}

Most patients with cirrhosis of the liver who are not on marked dietary sodium restriction have a defect in maximal concentrating ability $\left(\mathrm{U}_{\max }\right)$ but normal negative free-water clearance. A defective delivery of sodium to the distal nephron is not a sufficient explanation for the $\mathrm{U}_{\max }$ defect. Increased medullary blood flow, possibly due to increased shunting of blood to the medulla, is postulated to explain the findings, since other causes for such a defect do not appear to be present.

\section{Acknowledgments}

We wish to thank Miss Ann Long and Mrs. Margaret Wilcox for supervising the care of the patients on the metabolic unit, Miss Sheila Dye for dietary supervision, and Dr. Hugo Muench for help in the statistical analysis of the data.

\section{References}

1. Papper, S. The role of the kidney in Laennec's cirrhosis of the liver. Medicine (Baltimore) 1958, 37, 299.

2. Schedl, H. P., and F. C. Bartter. An explanation for and experimental correction of the abnormal water diuresis in cirrhosis. J. clin. Invest. 1960, $39,248$.

3. Goldsmith, C., H. K. Beasley, P. J. Whalley, F. C. Rector, and D. W. Seldin. The effect of salt deprivation on the urinary concentrating mechanism in the dog. J. clin. Invest. 1961, 40, 2043.

4. Bacon, J. S. D., and D. J. Bell. Fructose and glucose in the blood of the foetal sheep. Biochem. J. 1948, 42, 397.

5. Higashi, A., and L. Peters. A rapid colorimetric method for the determination of inulin in plasma and urine. J. Lab. clin. Med. 1950, 35, 475.

6. Corcoran, A. C., and I. H. Page. A method for the determination of mannitol in plasma and urine. $\mathrm{J}$. biol. Chem. 1947, 170, 165.

7. Van Slyke, D. D., and G. E. Cullen. A permanent preparation of urease, and its use in the determination of urea. J. biol. Chem. 1914, 19, 211.

8. Gigli, G., and S. Giovanetti. La funzione renale nella cirrosi epatica. Riv. Gastro-ent. 1951, 3, 79.

9. Lindeman, R. D., H. C. Van Buren, and L. G. Raisz. Osmolar renal concentrating ability in healthy young men and hospitalized patients without renal disease. New Engl. J. Med. 1960, 262, 1306.

10. Zak, G. A., C. Brun, and H. W. Smith. Mechanism of formation of osmotically concentrated urine during antidiuretic state. J. clin. Invest. 1954, 33, 1064. 
11. Thomas, J. P., and F. C. Bartter. Relation between diuretic agents and aldosterone in cardiac and cirrhotic patients with sodium retention. Brit. med. J. 1961, 1, 1134.

12. Earley, L. E., M. Kahn, and J. Orloff. The effects of infusions of chlorothiazide on urinary dilution and concentration in the dog. J. clin. Invest. 1961, $40,857$.

13. Levinsky, N. G., and R. W. Berliner. The role of urea in the urine concentrating mechanism. J. clin. Invest. 1959, 38, 741.

14. Epstein, F. P., C. R. Kleeman, and A. Hendrikx. The influence of bodily hydration on the renal concentrating process. J. clin. Invest. 1957, 36, 629.

15. Relman, A. S., and W. B. Schwartz. The kidney in potassium depletion. Amer. J. Med. 1958, 24, 764.

16. Welt, L. G., W. Hollander, Jr., and W. B. Blythe. The consequences of potassium depletion. J. chron. Dis. 1960, 11, 213.
17. Rapoport, S., W. A. Brodsky, C. D. West, and B. Mackler. Urinary flow and excretion of solutes during osmotic diuresis in hydropenic man. Amer. J. Physiol. 1949, 156, 433.

18. Levitt, M. F., D. Hauser, M. Levy, and D. Polimeros. The renal concentrating defect in sickle cell disease. Amer. J. Med. 1960, 29, 611.

19. Heinemann, H. O., and M. W. Cheung. Renal concentrating mechanism in sickle-cell anemia. J. Lab. clin. Med. 1957, 49, 923.

20. Perillie, P. E., and F. H. Epstein. Sickling phenomenon produced by hypertonic solutions: A possible explanation for the hyposthenuria of sicklemia. J. clin. Invest. 1963, 42, 570.

21. Wirz, H. Kidney, water, and electrolyte metabolism. Ann. Rev. Physiol. 1961, 23, 577.

22. Georg, J., K. Mellemgaard, N. Tygstrup, and K. Winkler. Venoarterial shunts in cirrhosis of the liver. Lancet 1960, 1, 852. 